Семыкин С.E.

\title{
Особенности индивидуально-психологических характеристик моряков до и после рейса*
}

В настоящее время существует ряд профессий, которые можно отнести к разряду особо сложных. Одной из таких профессий является труд моряка. Специфичность деятельности моряков связана с социальной и сенсорной изоляцией, кумулятивным воздействием качки и вибрации, климато-зональными контрастами, круглосуточным режимом работы, повышенной интенсивностью, экстенсивной напряженностью трудовой деятельности. Все эти и ряд других экстремальных факторов оказывает влияние на всех работающих, независимо от их профессиональной принадлежности [3].

В исследованиях ряда авторов в основном рассматривается влияние перечисленных выше факторов на нервную систему, процесс труда (деятельность, переработка информации) с точки зрения инженерной психологии, изучающей особенности разных видов операторской деятельности моряков в контексте динамической связи элементов «человек-судно» $[1,2]$.

Мы не обнаружили у других авторов данных анализа психолого-акмеологических особенностей моряков. Поэтому целью нашего исследования, явилось изучение индивидуально-психологических характеристик моряков и до, и после рейса.

Изучение психологических и технических составляющих профессиональной деятельности плавсостава позволило выдвинуть предположение, что их профессиональная деятельность может вызывать стрессовые состояния, высокий уровень тревожности, наличие эмоциональных проблем, что, в конечном счете, может деформировать их психику и личность, и создавать условия для развития профессиональной деформации в целом.

В исследовании приняли участие 285 мужчин работников водного транспорта, проходящих ежегодное медицинское освидетельствование в 1-й клинической больнице г. Ростова-на-Дону. Возрастной диапазон испытуемых был от 20 до 52 лет.

В процессе исследования нами решались следующие задачи: сравнительное изучение существующего уровня тревожности и стресса у работников водного транспорта; исследование показателей межличностных отношений и поведения в группе у сотрудников торгового флота; изучение акцентуаций характера плавсостава и выявление индивидуально-личностных детерминант, влияющих на появление профессиональных деструкций у сотрудников торгового флота до и после рейса.

Математическая обработка данных осуществлялась с помощью методов математической статистики. Компьютерная обработка результатов проводилась по программам SPSS 11.0 и NCSS2000-PASS2000.

* Материалы представлены научным руководителем-зав.кафедрой психологии развития и акмеологии ЮФУ, доктором психологических наук, профессором Т.П. Скрипкиной 
Прежде всего, в группах плавсостава, исследованных до рейса и после рейса, изучался уровень стресса посредством методики М.Люшера. Было выявлено, что стрессовое напряжение чрезвычайно усиливается после рейса. Соответствующие показатели $40 \%$ и $23 \%$ соответственно. До рейса отклонение от аутогенной нормы и уровень тревожности ниже (33\% и 16\% соответственно), чем у плавсостава после рейса ( $45 \%$ и $27 \%$ соответственно). Итак, проведенное исследование показывает, что время, проведенное на корабле, негативно сказывается на эмоциональном состоянии плавсостава, что заключается в повышении уровня тревоги и стрессового напряжения практически вдвое.

Анализ литературы также показывает, что необходимость пребывания в ограниченном пространстве и в относительной социальной изоляции во время рейса, негативно сказывается на межличностных отношениях людей. В этой связи в банк методик была включена методика Т.Лири, позволяющая исследовать сдвиги в установках на межличностные отношения до и после рейса.

Данные показали, что у плавсостава до рейса наиболее выражены авторитарный и агрессивный типы отношения, носящие умеренный характер; после рейса наблюдается умеренная выраженность авторитарного типа и высокая выраженность агрессивного и подозрительного типов отношений.

Итак, как видно из полученных данных, время, проведенное в рейсе, негативно сказывается, на способностях моряков к конструктивным межличностным отношениям.

Полученные данные со всей очевидностью показывают, что негативное влияние профессиональной деятельности на эмоциональную, личностную и межличностную сферу моряков не может не сказываться на их социальном поведении. В этой связи в банк методик была включена методика «Q-сортировка» с целью выявления колебаний в показателях основных тенденций поведения плавсостава. Исходя из данных, полученных до рейса, можно сделать вывод о том, что у моряков выявлено наличие внутреннего стремления к принятию групповых стандартов и ценностей: социальных и морально-этических, образованию эмоциональных связей, как в своей группе, так и за ее пределами.

После рейса начинают преобладать тенденции к зависимости и необщительности, причем они становятся устойчивыми качествами личности, присущими практически всем работникам флота.

Полученные данные позволяют сделать следующие выводы.

Профессиональная деятельность за довольно короткий срок (в течение рейса, длящегося до шести месяцев) на статистически значимом уровне способствует увеличению агрессии в поведении, увеличивает независимость от группы и групповых норм и ценностей, что, по нашему мнению, способствует маргинализации в поведении. Существенно увеличивается уровень тревоги и стрессового напряжения.

Полученные различия почти по всем изучаемым параметрам дали возможность выдвинуть предположение о том, что особенности профессиональной деятельности 
моряков должны негативно влиять на их личностные особенности, деформируя многие качества, заостряя акцентуации характера. В этой связи следующей задачей данного исследования стало изучение выраженности акцентуаций характера до и после рейса.

Моряки были исследованы до и после рейса по методике Г.Шмишека. До рейса среднегрупповые показатели находятся в пределах относительной нормы, но по двум шкалам имеет место не сильно выраженная тенденция к заострению. Это шкалы, отражающие застревание и дистимность.

После рейса у плавсостава наблюдается значимое усиление застревающего и дистимногго типов акцентуации, а также повышается тенденция к демонстративности и эмотивности. Это можно описать как усиление у респондентов ригидности, инертности психических процессов, долгого переживания травмирующих событий. Испытуемые проявляют себя как люди, стремящиеся к уединению, к отстранению от интраперсональных контактов.

Полученные данные позволяют сделать вывод о том, что профессиональная деятельность оказывает негативное воздействие на их личностную и эмоциональную сферу, сферу межличностных отношений, что, прежде всего, проявляется в поведении.

Научная новизна заключается в том, что выявлены индивидуально-личностные детерминанты, влияющих на появление профессиональных деструкций у работников водного транспорта. Использование полученных данных дает возможность для организации более эффективных профессиональных реабилитационных программ, методик профотбора.

\section{Литература}

1. Татарский Н.Е., Панаётов А.И. Использование новых методик информатики в обеспечении профотбора плавсостава // УкрНИИ морской медицины, г.Одесса. Вісник морської медицини, № 1(13). 2001.

2. Лобенко А.А., Волянский В.Е. Адаптация человека к условиям мирового океана: Нейро-вегетативные аспекты.- К.: Здоров'я, 1997.- 127 с.

3. Кирилюк М.Л., Дубнер В.Г. Патогенетические механизмы формирования дисрегуляторной патологии у моряков // Вісник морської медицини, № 4 (12). 2000. 